\title{
English and Scottish ancestors in the regional populations of the province of Quebec (Canada)
}

\author{
Marc Tremblay \\ Département des sciences humaines et sociales, Université du Québec à Chicoutimi
}

\begin{abstract}
The Quebec population descends in most part from French immigrants who settled in the St Lawrence River valley during the seventeenth century. However, people from other European origins have also contributed to the early settlement of the Canadian province. By means of genealogical data spanning more than three centuries, this study aimed to measure the contributions of English and Scottish immigrants to the peopling of the Quebec regions. More than 5,000 genealogies were reconstructed using the BALSAC population database. These genealogies span more than ten generations on average. Immigrants of each origin were identified and linked to all their descendants in the genealogical samples. Results show that English and Scottish founders appear in the genealogies of all Quebec regions, although in different proportions. These founders and/or their descendants were integrated into the predominant French Catholic population during the eighteenth and nineteenth centuries.
\end{abstract}




\section{Introduction}

The Quebec population (8.2 million in 2015) descends in most part from French immigrants who settled in the St Lawrence River valley during the seventeenth century. ${ }^{1}$ However, people from other origins have also contributed to the early settlement of the Canadian province. ${ }^{2}$ Among these, there were a few English and Scottish immigrants (mostly men). ${ }^{3}$ Following the British conquest of New-France in 1760, thousands of new immigrants from England and Scotland came to Quebec. ${ }^{4}$ Although most of these immigrants were Protestants, some of them married FrenchCanadian Catholics and thus had descendants who can be traced in the genealogical records of the contemporary Quebec population. By means of genealogical data spanning nearly four centuries, this study aimed to measure and compare the contribution of these immigrants of English and Scottish origins to the peopling of the 17 Quebec regions.

This study is based on data from the BALSAC population database, which contains millions of linked records on the Quebec population from the early seventeenth century to the end of the twentieth century. Considering the richness of this historical data, few populations can be studied as profoundly as the Quebec population. Not only can studies based on the Quebec data inform on the history of the Quebec population since its foundation, but they can also bring new insights on the formation and evolution of regional populations in general. Findings presented in this article will help better understand the role and impact of English and Scottish pioneers to the development of the Quebec population and should thus be of interest to the readers of this journal.

\section{Brief history of the Quebec population}

The province of Quebec is located in the eastern part of Canada (Figure 1). It is the largest province of the country, with approximately 1.7 million square kilometers. Its population of 8.2 million is the second largest after that of the neighboring province of Ontario. About 80 per cent of the Quebec population is French-speaking. ${ }^{5}$

${ }^{1}$ H. Charbonneau, B. Desjardins, J. Légaré and H. Denis, 'The population of the St Lawrence Valley, 1608-1760', in M. R. Haines and R. H. Steckel eds, A Population History of North America (Cambridge, 2000), 99-142.

${ }^{2}$ Charbonneau, et al., 'The population of the St Lawrence Valley'; J. Bergeron, H. Vézina, L. Houde and M. Tremblay $\mathrm{M}$, 'La contribution des Acadiens au peuplement des régions du Québec’, Cahiers québécois de démographie, 37-1 (2008), 181-204; M. Tremblay, M. Letendre, L. Houde and H. Vézina H, 'The contribution of Irish immigrants to the Quebec (Canada) gene pool: an estimation using data from deep-rooted genealogies', European Journal of Population, 25-2 (2009), 215-33; M. Tremblay, 'La contribution des immigrants d'origine germanique au peuplement des régions de Lanaudière, de la Mauricie, de la Montérégie, de ChaudièreAppalaches et du Bas-Saint-Laurent' Cahiers québécois de démographie, 39-2 (2010), 179-200.

3 D. Dobson, Scottish Emigration to Colonial America, 1607-1785 (Athens, Georgia, 1994); M. Fournier, Les Européens au Canada des origines à 1765 (Hors France) (Montreal, 1989).

${ }^{4}$ J. Henripin, La métamorphose de la population canadienne (Montreal, 2003); R. Beaujot and D. Kerr, Population Change in Canada, 2nd edn (Oxford, 2004).

${ }^{5}$ Institut de la statistique du Québec, http://www.stat.gouv.qc.ca/ [2 November 2015]. 
European settlement in Quebec began in the early seventeenth century. Quebec City was founded by the French explorer Samuel de Champlain in 1608, but significant colonization of the territory started a little later (mid-seventeenth century). At first, most of the newcomers were either military, clergy or young men recruited for the fur trade or as laborers. ${ }^{6}$ During the 1660s, in order to stimulate the growth of the population, the French king Louis XIV sent some 800 Filles $d u$ Roi who were rapidly married to the settlers. ${ }^{7}$ Between 1650 and 1700, the population increased from a mere 2,000 to nearly $18,000 .^{8}$

At the end of the French Regime (1760), the Quebec population had reached 70,000 people. The takeover by the British halted the immigration from France. From then on, immigrants came mainly from the British Isles or colonies. After the American Revolution (1776-1783), many Loyalists came to Quebec. ${ }^{9}$ Some German mercenaries, who were recruited into the British army during the war, also settled in the province. ${ }^{10}$ The end of the Napoleonic wars in 1815 initiated a new period of strong immigration to North America. English and Scottish immigrants came first, followed by Irish settlers during the mid-nineteenth century. ${ }^{11}$ Contrary to the English and Scottish, most of the Irish immigrants who chose to settle in Quebec were Catholics. ${ }^{12}$

At the beginning of the twentieth century, a diversification of immigration took place, with the arrival of thousands of immigrants from central and eastern Europe. ${ }^{13}$ These new immigrants settled mainly in the western part of Canada, but some remained in Quebec. Since the 1960s, immigrants from all parts of the world have been coming to Canada. Europe is no longer the main source of immigrants: in recent years, over half of the newcomers have been born in Asian countries. ${ }^{14}$ Latin America and Africa have also contributed a good part of the immigration movement during the last decades.

${ }^{6}$ J. Dickinson and B. Young, A Short History of Quebec (Montreal, 2008).

${ }^{7}$ Y. Landry, Les Filles du roi au XVIIe siècle (Montreal, 1992).

${ }^{8}$ Charbonneau, et al., 'The population of the St Lawrence Valley'.

${ }^{9}$ M. McInnis, 'The population of Canada in the nineteenth century', in M. R. Haines and R. H. Steckel eds, A Population History of North America (Cambridge, 2000), 371-432.

${ }^{10} \mathrm{~V}$. De Marce, The settlement of former German auxiliary troops in Canada after the American Revolution (Sparta, Wisconsin, 1984).

${ }^{11}$ C. J. Houston and W. J. Smyth, Irish emigration and Canadian settlement: patterns, links, and letters (Toronto, 1990); M. McLean, People of Glengarry: Highlanders in Transition, 1745-1820 (Montreal, 1991); L. H. Campey, Les Écossais. The Pioneer Scots of Lower Canada, 1763-1855 (Toronto, 2006); L. H. Campey, Seeking a Better Future. The English Pioneers of Ontario and Quebec (Toronto, 2012).

12 R. J. Grace, 'Irish immigration and settlement in a Catholic city: Quebec, 1842-61', The Canadian Historical Review, 84-2 (2003), 219-51.

${ }^{13}$ M. McInnis, 'Canada's population in the twentieth century', in M. R. Haines and R. H. Steckel eds, A Population History of North America (Cambridge, 2000), 529-99.

${ }^{14}$ Statistics Canada, Immigration and Ethnocultural Diversity in Canada, Catalogue no. 99-010X2011001 (Ottawa, 2013). 
For most of its history, the French-Canadian population maintained high fertility levels, averaging between six and eight children per women up to the end of the nineteenth century. ${ }^{15}$ This high fertility allowed for a sustained growth of the population. From the end of the French Regime in 1760 to the mid-twentieth century, the total population of the province of Quebec grew from 70,000 to 4,000,000 people, for an average annual growth rate of approximately 2.1 per cent.

\section{The 17 Quebec regions}

Most of the Quebec population is concentrated on both sides of the St Lawrence River (see Figure 1 and Table 1). The first settlements were located between Montreal (region 06) and Quebec City (region 03). During the nineteenth century, regions further north and east were colonised. The newest regions are those of Abitibi-Témiscamingue (08) and Nord-du-Québec (10), whose development was spurred by forest and mining industries.

The Montreal region (06) is the most highly populated, followed by Montérégie (16) which is located just south of Montreal. The Capitale-Nationale region (03), comprising Quebec City, is the main population center of the eastern part of the province. The largest regions (Nord-duQuébec, Côte-Nord, Saguenay-Lac-Saint-Jean and Abitibi-Témiscamingue) are also the less densely populated.

\section{Settlement of English and Scottish immigrants in Quebec}

Even though most of English and Scottish settlers in Quebec came after the British conquest, a few of them were established during the French Regime. ${ }^{16}$ These early emigrants were mostly Catholic, and it is believed that they were quickly assimilated into the French-speaking majority. ${ }^{17}$ This situation changed rapidly after 1760, when English and Scottish Protestants began to settled in the Quebec territory. Many new English-speaking (and even Gaelic-speaking) communities were formed in several parts of Quebec, giving rise to a number of localities bearing English and Scottish names still used today. ${ }^{18}$ However, in many of these places, subsequent outmigration waves of British settlers or their descendants and in-migration of French-Canadians radically transformed the ethnic composition of the population. For instance, many Englishspeaking people from the Eastern Townships (Estrie region), where most of the earliest settlers were of British origin, chose to emigrate to other parts of Canada or the United States during the second half of the nineteenth century. The vacated territory was quickly occupied by French-

15 J. Henripin and Y. Péron, 'The demographic transition of the Province of Quebec', in D. V. Glass and R. Revelle eds, Population and social change (London, 1972), 213-31; Charbonneau, et al., The population of the St Lawrence Valley.

${ }^{16}$ D. Dobson, Scottish Emigration to Colonial America; M. Fournier, Les Européens au Canada.

${ }_{17}^{17}$ M. Fournier, Les Européens au Canada.

18 J. Ouellet, 'Des Écossais au Canada et jusqu'à Rivière-du-Loup du XVIIe au XXe siècle' Histoire Québec, 10-2 (2004), 22-25; L. H. Campey, Les Écossais; L. H. Campey, Seeking a Better Future; P. Langlois-Thibault, 'Divers groupes s'établissent dans les Laurentides', Histoire Québec, 16-3 (2011), 15-20; J,-M. Fallu, 'La Gaspésie british’, Magazine Gaspésie, 51-1 (2014), 5-10. 
Canadians. ${ }^{19}$ In 1881, people of Scottish ancestry still accounted for the majority of the population in some townships, but by 1941 they represented only 5 per cent of the population of the Estrie region. ${ }^{20}$ In the Gaspésie region, where British settlers were already present at the end of the eighteenth century, the population of British origin declined from 50 per cent in the middle of the nineteenth century to about 20 per cent in $1931 .{ }^{21}$ Nowadays, the vast majority of the English-speaking population of Quebec lives in or around the Montreal region. ${ }^{22}$

Because they were Catholic and French-speaking, French-Canadians did not intermarry frequently with Anglo-Protestants. However, some mixed marriages did occur right from the beginning of the British Regime during the 1760s. ${ }^{23}$ Children of British immigrants who were born in Quebec also had the opportunity to mix with French-Canadians. Hence, the contemporary French-Canadian population of Quebec has a number of English and Scottish pioneers among its ancestors. The contribution of these British settlers to the peopling of Quebec and its regions is certainly less important than that of the early French pioneers, but it has never been measured precisely. Most importantly, although the history of English and Scottish settlements in Quebec has been the subject of a number of previous studies, little is known about their lasting impact on the contemporary population of the Quebec regions. This study will shed new light on this aspect of the demographic history of Quebec.

\section{Data and methods}

Data for this study was retrieved from the BALSAC population database. ${ }^{24}$ This database contains demographic and genealogical data on the population of Quebec from the seventeenth to the twentieth century. Most of the information used to construct the BALSAC database comes from Catholic Church records (birth, marriage and death records), which have been carefully kept since the early days of the colony. ${ }^{25}$ For the present study, additional material was obtained from several Canadian census files (from 1851 to 1921).

19 J. I. Prattis, 'Ethnic Succession in the Eastern Townships of Quebec', Anthropologica, 22-2 (1980), 215-234; M. Bilodeau, 'La présence écossaise dans les Cantons de l’Est', Histoire Québec, 8-1 (2002), 13.

${ }^{20}$ L. H. Campey, Les Écossais.

21 J.-M. Fallu, 'La Gaspésie British'; H. Vézina, M. Tremblay, È.-M. Lavoie and D. Labuda, 'Concordance between reported ethnic origins and ancestral origins of Gaspé peninsula residents', Population-E, 69-1 (2014), 7-28.

${ }^{22}$ Institut de la statistique du Québec, http://www.stat.gouv.qc.ca/ [2 November 2015].

${ }^{23}$ M. Tremblay, H. Vézina, B. Desjardins and L. Houde, 'Distant kinship and founder effects in the Quebec population', in T. Bengtsson and G. P. Mineau eds, Kinship and Demographic Behavior in the Past (Dordrecht, 2008), 259-77.

${ }^{24}$ BALSAC Project, http://balsac.uqac.ca/english/ [2 November 2015].

25 B. Desjardins, 'Le Registre de la population du Québec ancien', Annales de démographie historique, 1998-2 (1998), 215-26. Some other, non-Catholic records have also been used for the reconstruction of the genealogies, but compared with Catholic records, they are less complete and do not contain as much information needed for the genealogical linkage process. Hence, nonCatholic English and Scottish immigrants with no descendant married in the Catholic Church may not be identified in this study. 
The structure of BALSAC is based on the linkage process, by which genealogical links between individuals are established. This process is made possible by the fact that Catholic marriage records contain the names and surnames of the parents of each spouse. Every individual can then be linked to his/her two parents, then to his/her four grand-parents, and so on. ${ }^{26}$ The richness of the BALSAC database provides a high genealogical depth, which is a most valuable asset to better understand the origins of a population and the structure of the genealogical links between individuals. $^{27}$

\section{Genealogical reconstruction}

A total of 5,100 ascending genealogies were reconstructed for this study. Subjects (the starting points of the genealogies) are individuals who were married between 1966 and 1985 in one of the 17 Quebec regions. Three hundred marriages from each region were chosen at random among the available marriage records, then one spouse per marriage was randomly selected. Each genealogical branch goes back as far as the first immigrants who came to Quebec (defined as the founders). The origins of the founders correspond either to their place of birth or their last place of residence before emigration. In most cases, the exact date of emigration to Quebec is not known. Hence, the founder's date of marriage was used as a proxy.

\section{Genealogical analysis}

Several measures were used to describe and analyze the genealogical data. These measures include: the total number of ancestors identified; the completeness of the genealogies per generation, that is, the proportion of ancestors identified at each generational level; the mean genealogical depth, which corresponds to the average length of the genealogical branches; and the genetic contribution of the founders, which depicts the proportion of the gene pool in the population that comes from each founder. ${ }^{28}$

The calculation of the genealogical completeness and the mean genealogical depth is illustrated in Figure 2. In this example, which is limited to four generations of ancestors, completeness (Cg) at the first (parents of the subject) and second (grand-parents) generations is 100 per cent. At the third generation (great-grand-parents), completeness falls to 75 per cent since one couple of ancestors is not known. At the fourth generation, only 62.5 per cent of ancestors are known.

${ }^{26}$ For more information about linkage procedures used in the BALSAC database, see G. Bouchard, R. Roy, B, Casgrain and M. Hubert, 'Computer in human sciences: from family reconstitution to population reconstruction', in E. Nissan and K. M. Schmidt eds, From information to knowledge: conceptual and content analysis by computer (Oxford, 1995), 201227.

${ }^{27}$ C. Scriver, 'Human genetics: lessons from Quebec populations', Annual Review of Genomics and Human Genetics, 2 (2001), 69-101.

${ }^{28}$ M. Jomphe, M. Tremblay, H. Vézina, Analyses généalogiques à partir du fichier RETRO, Document Projet BALSAC no I-C-215 (Chicoutimi, 2014); M.-H. Cazes and P. Cazes, 'Comment mesurer la profondeur généalogique d'une ascendance', Population, 51 (1996), 11740; E. Heyer and M. Tremblay, 'Variability of the genetic contribution of Quebec population founders associated to some deleterious genes', The American Journal of Human Genetics, 56 (1995), 970-8. 
Summing the completeness gives a mean genealogical depth of 3.375 (out of a maximum of 4) for this genealogy.

The genetic contribution can be defined as the proportion of the subjects' gene pool that is attributable to each group of founders. ${ }^{29}$ This definition is based on the probability that a given gene introduced by a founder in the population was transmitted, from generation to generation, to his/her descendants in the contemporary population. It takes into account both the number of occurrences of the founders in the genealogies and the distance, in number of generations, between the founders and the subjects. For example, the genetic contribution of each parent to a given subject is 0.5 , that of each of his four grand-parents is 0.25 , etc. The sum of the genetic contribution of the founders for a given subject is equal to 1 (see Figure 3). Hence, the proportion of the subjects' gene pool in a region that is explained by a given group of founders equals the sum of the genetic contribution of these founders to the subjects of the region, divided by the number of subjects from the same region. ${ }^{30}$

\section{Results}

\section{Characteristics of the genealogies}

With the exceptions of two regions, more than one million mentions of ancestors were found in the genealogies of each region (Table 2). However, since many of these ancestors appear several times in the genealogies, the number of distinct ancestors is much lower, varying between 36,077 (region 11) and 75,215 (region 13). On average, ancestors appear between 14 (regions 06 and 16) and 34 (region 02) times, but variances associated to these average values are high: nearly half of ancestors appear only once, while some ancestors appear more than 5,000 times in the genealogies of a single region. Early ancestors (the founders) have the highest occurrences. Regions with the highest numbers of occurrences per ancestor are often considered as genetically more homogeneous than other regions. ${ }^{31}$

The genealogies span ten generations on average, with a maximum depth of 16 to 18 generations. The genealogical completeness is at least 90 per cent up to the eight generation (Figure 4), which means that nine ancestors out of ten could still be identified at this level. Few population databases can offer such a high genealogical depth. After the ninth generation, the completeness falls rapidly as the genealogical branches reach the first immigrants to Quebec (the founders).

\section{Characteristics of English and Scottish founders}

A total of 194 English and 122 Scottish founders were identified in the genealogies, representing respectively 1.9 and 1.2 per cent of all founders (Table 3). English and Scottish founders appear

${ }^{29}$ C. Bherer, D. Labuda, M.-H. Roy-Gagnon, L. Houde, M. Tremblay and H. Vézina, 'Admixed ancestry and stratification of Quebec regional populations', American Journal of Physical Anthropology, 144 (2011), 432-41.

${ }^{30}$ For more details about the genetic contribution of founders in a population, see E. Heyer, 'Genetic consequences of differential demographic behaviour in the Saguenay region, Québec', American Journal of Physical Anthropology, 98 (1995), 1-11.

${ }^{31}$ C. Scriver, 'Human genetics: lessons from Quebec populations'. 
in the genealogies of all 17 Quebec regions, although in different proportions. It is interesting to note that the proportions of English and Scottish founders in each region are lower than their proportions among all genealogies. This observation is explained by the fact that a greater proportion of the other founders (mostly of French origin) appear in multiple regions, whereas most English and Scottish founders appear in less than four regions. All things being equal, the probability of appearing as a founder in the genealogies grows with the number of generations separating the founder and the subjects. Since most of the French founders settled earlier in Quebec than the British founders, they appear, on average, in more genealogies.

Table 4 shows the distribution of English and Scottish founders according to sex and period of marriage. In both cases, there are more men than women. This is in accordance with the type of immigration that characterised North American colonies from the seventeenth to the nineteenth century. ${ }^{32}$ Most founders were married between 1760 and 1860, after the British takeover of Canada. A few British founders, mostly English, arrived during the French Regime. The earliest English founder is a woman named Suzanne Betfer, from Gloucester, who settled in Quebec City (region 03) as early as 1649. The earliest Scottish founder is a man named John Reid, from Inverness, who was married in the village of La Prairie (region 16) in 1714.

Because of lack of information in the available historical sources, precise origins are not known for all founders. In fact, a place of origin more precise than simply England or Scotland was found for only 45 per cent of English and 61 per cent of Scottish founders. Nevertheless, it is interesting to have a look at these origins because they may be representative of the origins of all English and Scottish founders who came to Quebec (see Table 5). Results suggest that British founders in Quebec came from all over England and Scotland, as was expected from previous studies on English and Scottish settlements in Quebec. ${ }^{33}$ However, a few places seem to have provided a particular high proportion of founders. This is the case, for instance, of the northern counties of Scotland: Aberdeenshire, Inverness-shire, the Hebrides and Ross and Cromarty account for a little more than half of all Scottish founders, whereas the population of these counties represented approximately 15 per cent of the population of Scotland at the end of the eighteenth century. ${ }^{34}$ On the English side, one third of the founders came from London (11 per cent of England population in 1801) and 14 per cent from Lancashire (8 per cent of the population). ${ }^{35}$ In this case however, the proportions of founders from London and Lancashire may have been increased by the fact that these two places served as departure ports (Liverpool in Lancashire) for many emigrants. ${ }^{36}$ It should be noted that Jersey (although not formally a part of England) also supplied a good number of founders to Quebec.

\section{Regional presence and genetic contribution}

To better understand the regional impact of English and Scottish settlers in the Quebec population, the proportion of genealogies in which these founders appear and their genetic

${ }^{32}$ M. R. Haines and R. H. Steckel eds, A Population History of North America.

${ }^{33}$ L. H. Campey, Les Écossais; L. H. Campey, Seeking a Better Future.

${ }^{34}$ Histpop - The online historical population reports, http://www.histpop.org/, [6 October 2015].

35 E. A. Wrigley, 'Rickman revisited: The population growth rates of English counties in the Early Modern period’, The Economic History Review, 62-3 (2009), 711-35.

${ }^{36}$ L. H. Campey, Seeking a Better Future. 
contribution are illustrated on four maps showing the 17 Quebec regions (see Figures 5 to 8). The intervals of proportions in each pair of maps are identical, allowing a direct comparison between the two groups of founders.

Between 16 and 70 per cent of the regional genealogies contain at least one English founder (Figure 5), whereas Scottish founders appear in 5 to 39 per cent of the genealogies (Figure 6). English founders appear more frequently in the western regions of the province (around Montreal), as expected according to historical data. ${ }^{37}$ The concentration of Scottish founders is higher in the northern and eastern regions (01, 02, 09 and 10), which is a bit surprising. Most founders appear in less than four different regions, but a few of them are found in the genealogies of all 17 Quebec regions.

The genetic contribution of the two groups of founders also varies greatly according to the region (Figures 7 and 8). However, these variations differ from those in the previous figure. This means that the occurrences of the founders of each origin in the genealogies are not uniform across all regions. For instance, Scottish founders who were identified in the genealogies of the SaguenayLac-St-Jean region (02) have the second highest genetic contribution, whereas the proportion of genealogies in which they appear is much lower than that of most English founders. Another example is given by the English founders in the genealogies of region 11: they have the third highest genetic contribution overall but do not appear particularly frequently among the genealogies of this region. On the whole, the genetic contribution of English founders is usually higher than that of Scottish founders. The highest value is that of the English founders in the genealogies of the Montérégie region (16), where almost one per cent of the subjects' gene pool is explained by these founders. This proportion is a little higher than the proportion of English founders among all founders identified in the genealogies of region 16, but this is an exception. Indeed, apart from this case and that of the Scottish founders of the Saguenay-Lac-St-Jean region (02), the genetic contribution of English and Scottish founders is lower than their respective proportion among all founders of each region. Again, the main reason for this is that these founders arrived on average at a later date than the predominant French founders, who gained a clear advantage in terms of total number of descendants in the contemporary population.

It is interesting to point out that English and Scottish founders most probably had themselves French or other European origins. A recent paper published in the journal Nature depicts distinct genetic clusters in the UK population showing various European genetic contribution corresponding to the main migration events that occurred during British history. ${ }^{38}$ For instance, the results of this study showed that the population of southern England, whence originated a high proportion of the English founders of Quebec, has strong genetic links with the population of northwestern France, from where came the most important founders of the Quebec population. This is also the case for the populations of the outer Hebrides and northwest Scotland

${ }^{37}$ S. Olson and P. Thornton P, 'La croissance naturelle des Montréalais au XIXe siècle’, Cahiers québécois de démographie, 30-2 (2001), 191-230.

${ }^{38}$ S. Leslie, B. Winney, G. Hellenthal, D. Davison, A. Boumertit, T. Day, K. Hutnik, E.C. Royrvik, B. Cunliffe, Wellcome Trust Case Control Consortium 2, International Multiple Sclerosis Genetics Consortium, D.J. Lawson, D. Falush, C. Freeman, M. Pirinen, S. Myers, M. Robinson, P. Donnelly and W. Bodmer, 'The fine-scale genetic structure of the British population', Nature, 519 (2015), 309-14. 
(Aberdeenshire). These populations also have strong genetic links with the population of western Germany.

\section{The Top Ten lists}

Table 6 presents detailed information about the most important English and Scottish founders identified in the genealogies of the Quebec population. On the English side, these are founders who appear in the genealogies of at least twelve Quebec regions, whereas the top ten Scottish founders appear in the genealogies of at least ten regions.

Most of these founders bear surnames that are quite typical of their geographical origin, although some English surnames, such as Boire and Renaud, seem perhaps more French than English. What is striking is that all English founders married someone of French origin. This result is in accordance with the fact that descendants of these couples are found in so many Quebec regions. Most Scottish founders also married French spouses, with the exception of two founders (Duncan McNicoll and Catherine Nicolas) who were married together.

These most important founders were married much earlier, on average, than the other founders. This is especially notable among the top ten English founders, whose average year of marriage is 1696, compared with 1812 for all English founders. Again, this result concords with the important contribution of these founders: all things being equal, a founder who arrived earlier in the colony has a greater chance of having a large descendance in the contemporary population than a founder who arrived at a later date.

The larger contemporary descendance of these founders is also due to their relatively high number of children who married in the province of Quebec. ${ }^{39}$ On average, the top ten English founders had nearly five married children, whereas the Scottish founders had a little over seven married children. The record of twelve married children for Hugh Blackburn and Geneviève Gagnon is particularly remarkable, considering the high child mortality at that time. ${ }^{40}$ In contrast, only one married child for Samuel Ricasse and Charlotte Choret is a bit surprising, considering that descendants of this couple are found in all 17 regions of Quebec. Further research in the BALSAC database showed that their daughter also had only one married child (a son) who himself had four children who married in Quebec at the end of the eighteenth century.

\section{Conclusion}

The main objective of this study was to identify founders of English and Scottish origins who contributed significantly to the peopling of the province of Quebec since the beginning of the European settlement in the seventeenth century. A corpus of 5,100 ascending genealogies of subjects from the contemporary population was reconstructed for this purpose. These genealogies proved to be very substantial, thanks to the high quality of the BALSAC population database.

\footnotetext{
${ }^{39}$ Married children of the 20 founders were identified using the BALSAC database. Hence, these children were married in Quebec. Some other children may have married outside the Quebec territory.

${ }^{40}$ Charbonneau, et al., The population of the St Lawrence Valley.
} 
A little more than three hundred British founders were identified. These founders, mostly men, immigrated to Quebec as early as the seventeenth century, although most of them came at the end of the eighteenth century or during the first half of the nineteenth century. They came from various regions of England and Scotland, with a certain overrepresentation from London and the Highlands. Although the contribution of English and Scottish founders to the peopling of the Quebec regions remain relatively small in comparison with those of the French founders, results of this study showed that many of these founders and/or their descendants were integrated into the predominant French Catholic Quebec population during the eighteenth and nineteenth centuries. Contemporary descendants of these immigrants can be found in all regions of Quebec, but some regions clearly experienced a stronger British impact than others. Also, English and Scottish contribution differs according to the region, with higher values for the English founders in most regions.

It is important to remember that the founders identified in this study are immigrants who were presumably born in England or Scotland. Hence, founders with British ancestry who were born in another Canadian province, in the United States of America or in other British colonies were not counted as English or Scottish founders. Also, since this study was based mainly on data retrieved from Catholic records, the contribution of English and Scottish founders to the population of Quebec may be underestimated. It is hard to give a precise measure of this underestimation. Considering that most of their descendants married into the Catholic church, one can assume that the missing numbers are not large. The most important genetic contributors were certainly identified in the genealogies.

\section{Acknowledgements}

The author wishes to thank Ève-Marie Lavoie, Michèle Jomphe (research professionals at the BALSAC Project), Laurent Richard (research professional at the Centre interuniversitaire d'études québécoises), Gabrielle Rouleau, Sara-Jeanne Lemieux, Laurence Côté-Lavoie and David Grant-Poitras (students at the Université du Québec à Chicoutimi) for their technical assistance. Financial support for this study was provided by the Social Sciences and Humanities Research Council of Canada and by the Fonds de recherche du Québec - Société et culture. 
Figure 1: The 17 Quebec regions

Source : Institut de la statistique du Québec (2015).

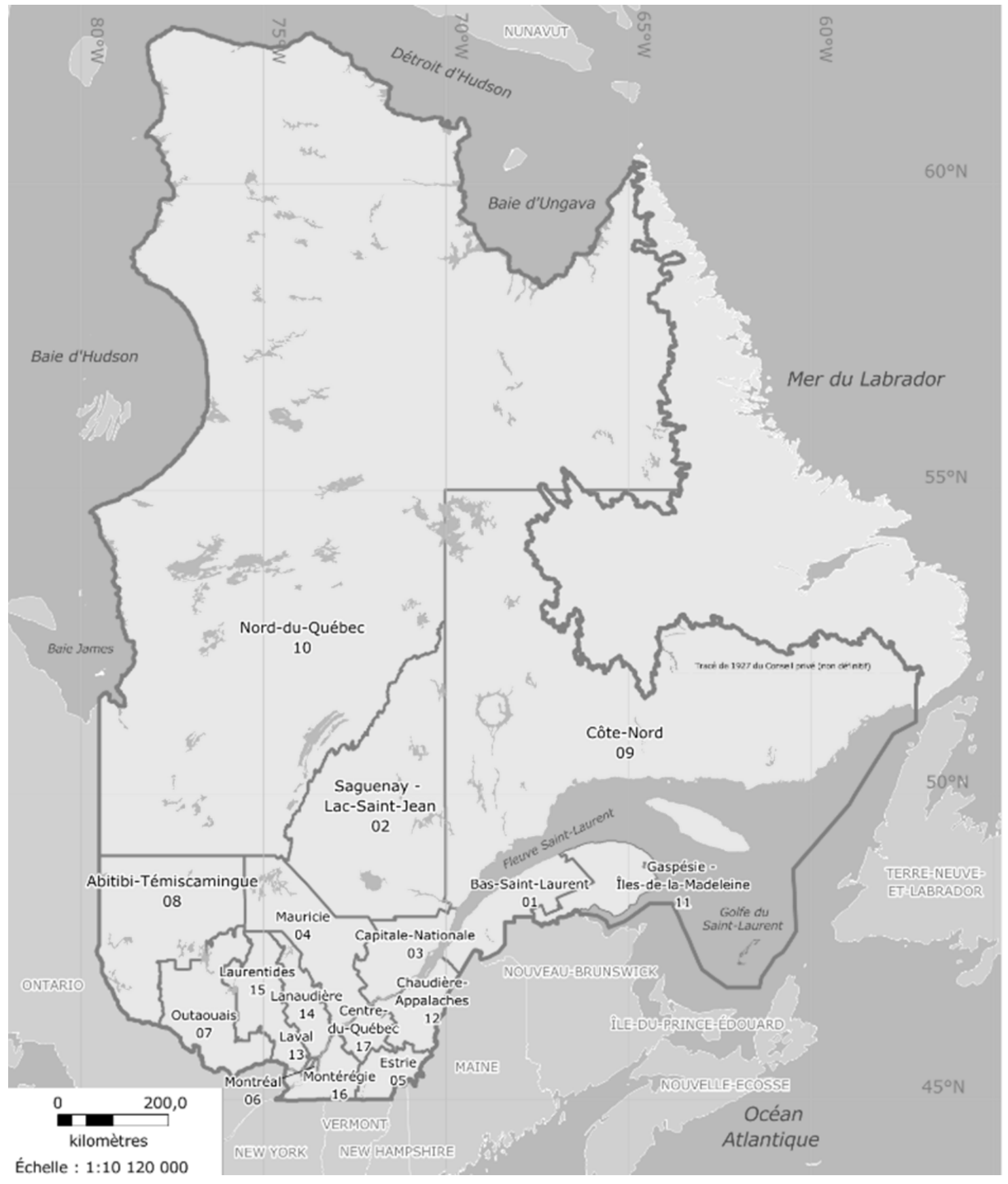


Figure 2: Genealogical completeness and mean genealogical depth: an example with four generations of ancestors

Note : The genealogical completeness $\left(\mathrm{C}_{\mathrm{g}}\right)$ is the proportion of ancestors identified in the genealogies at each generation, based on a maximum value of $2^{\mathrm{n}}$ ancestors ( $\mathrm{n}=$ generation level). The mean genealogical depth (MGD) is obtained by summing all genealogical completeness.

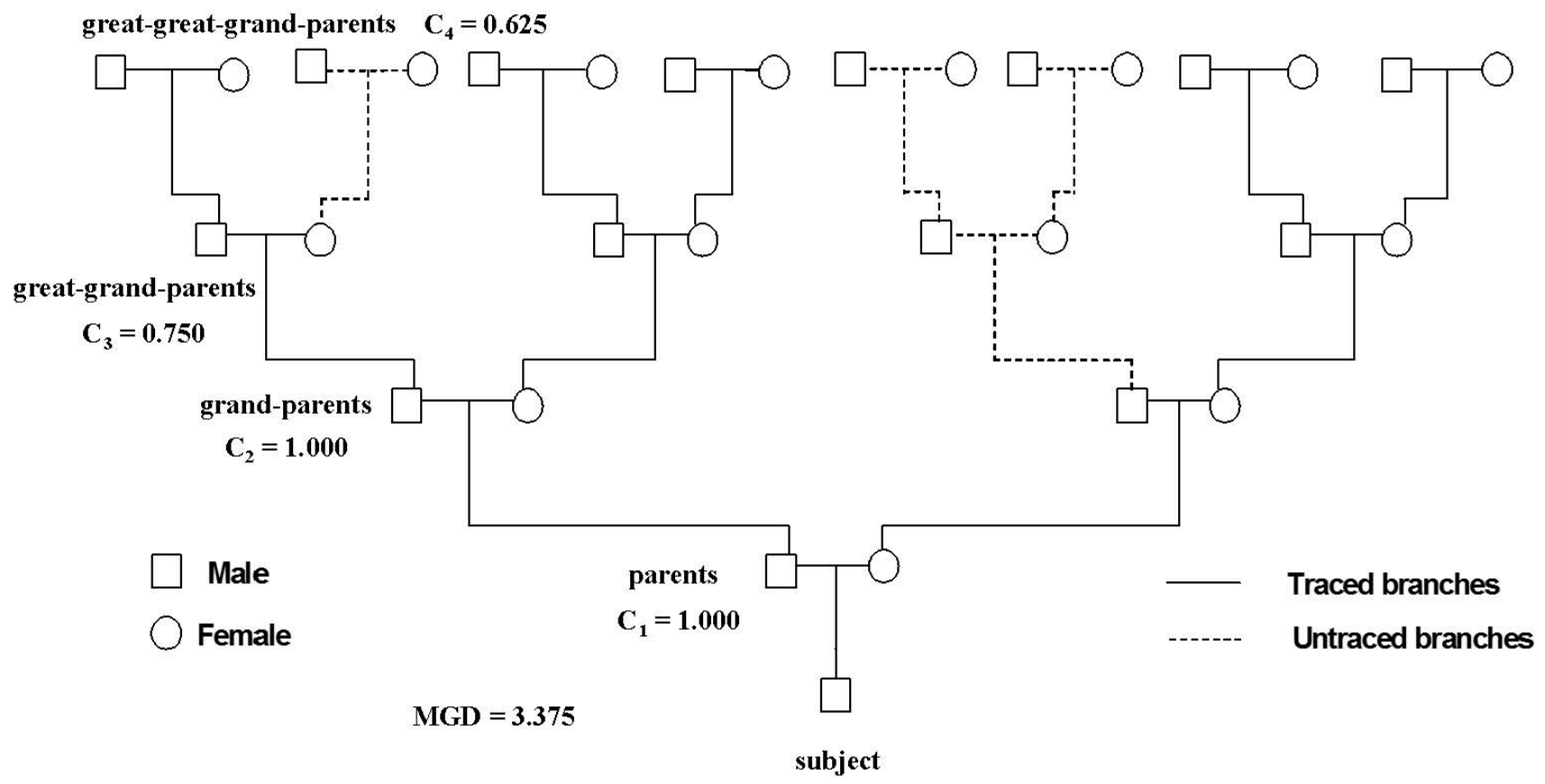




\section{Figure 3: Genetic contribution of founders to a subject}

Note: In this example, the subject's genealogy shows ten founders ( $F_{1}$ to $\left.F_{10}\right)$. The genetic contribution of $F_{1}$ (the subject's paternal grand-mother) is equal to 0.25 . Founders $F_{2}, F_{3}$ and $F_{4}$ (three of the subject's great-grand parents) each have a genetic contribution of 0.125 . Lastly, the genetic contribution of each founder $F_{5}$ to $F_{10}$ is equal to 0.0625 . The sum of the genetic contribution of the ten founders is equal to 1 (100 per cent of the subject's genes come from these ten founders).

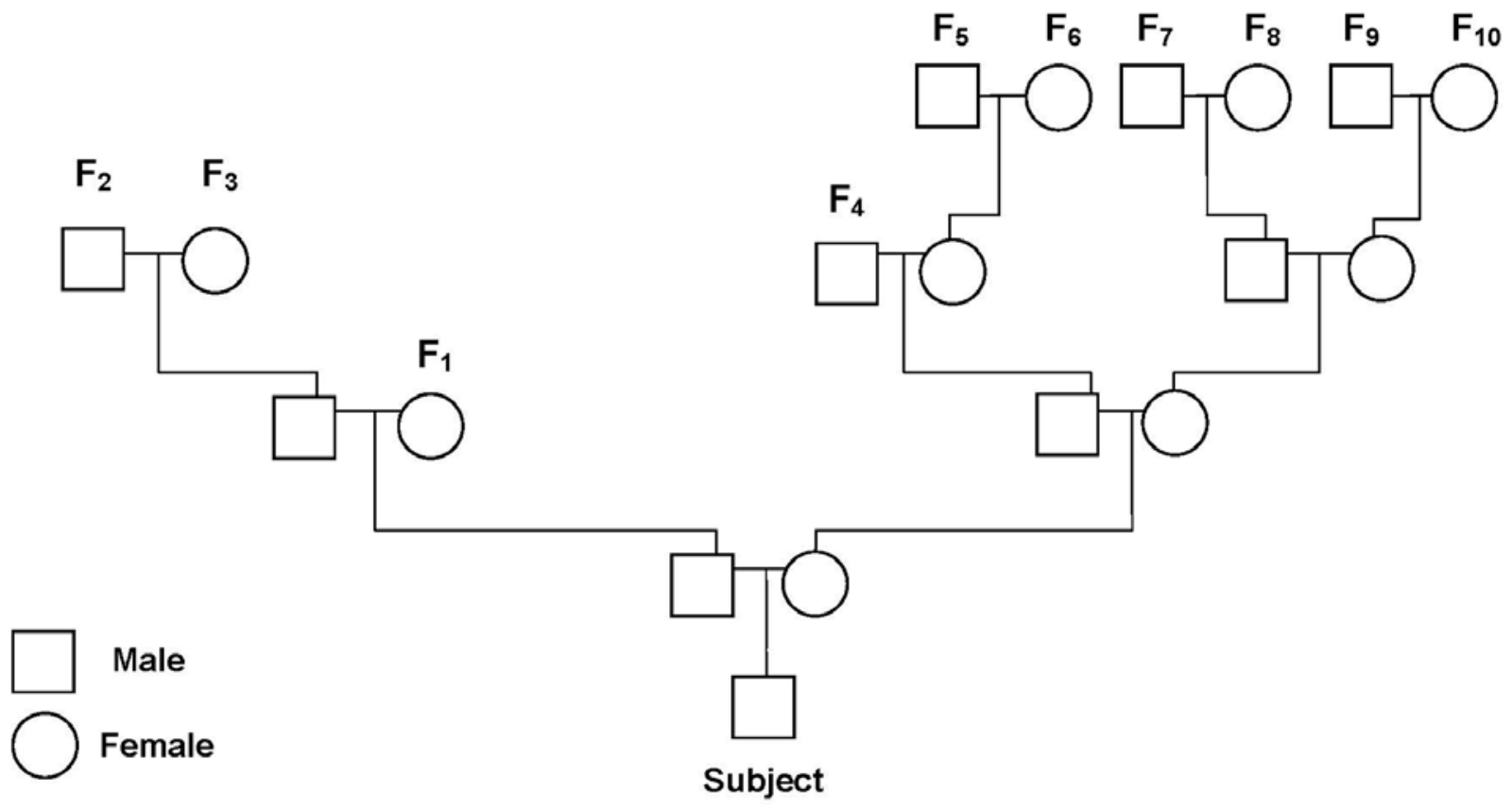


Figure 4: Mean completeness (\%) of the genealogies, up to the $15^{\text {th }}$ generation

Note : Generation 1 is that of the subjects' parents, generation 2 is that of the subjects' grandparents, etc.

Source : BALSAC population database.

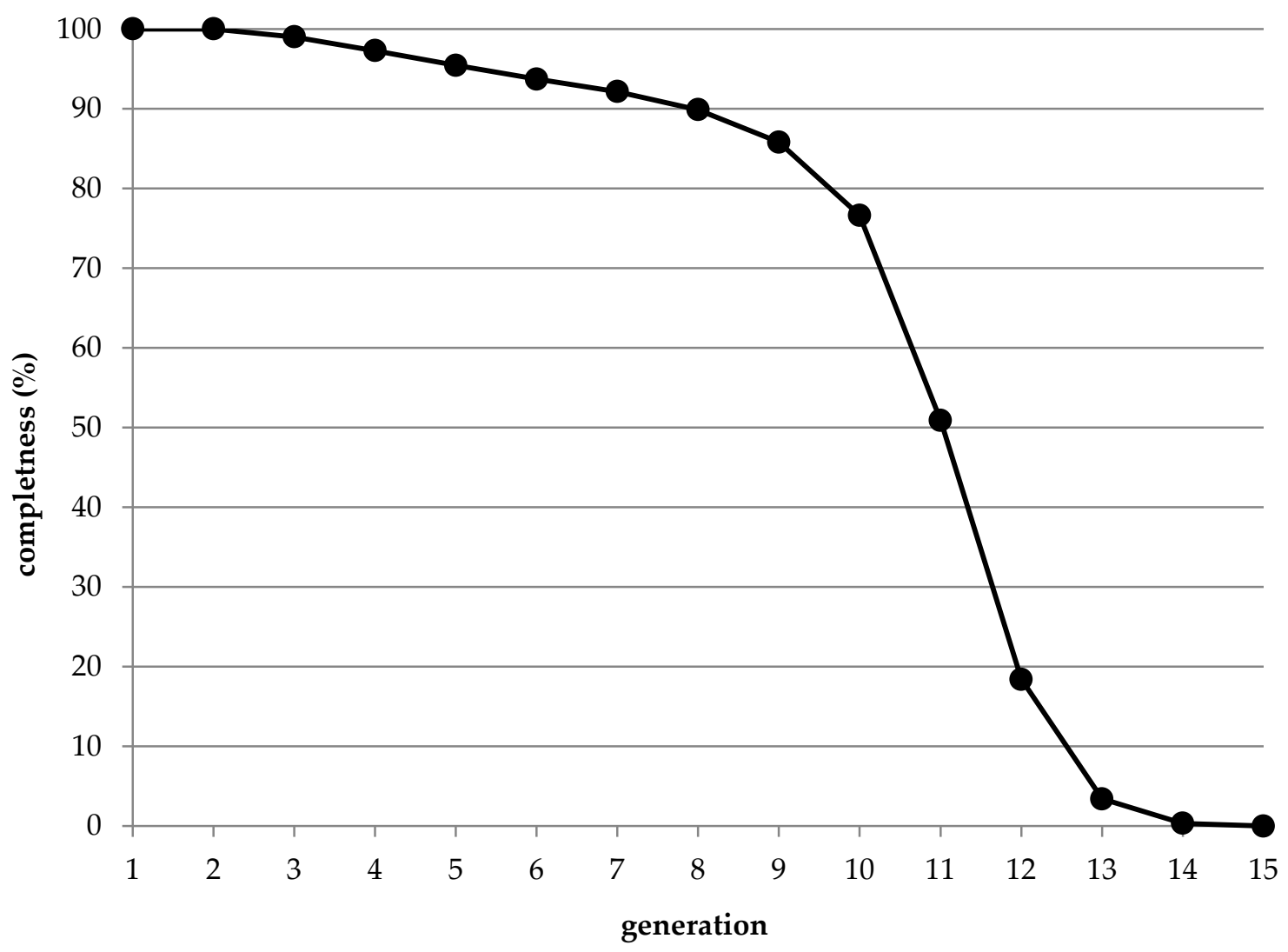


Figure 5: Proportion (\%) of genealogies in each Quebec region containing at least one English founder

Note : Map produced at the Centre interuniversitaire d'études québécoises. Source of data : BALSAC population database.

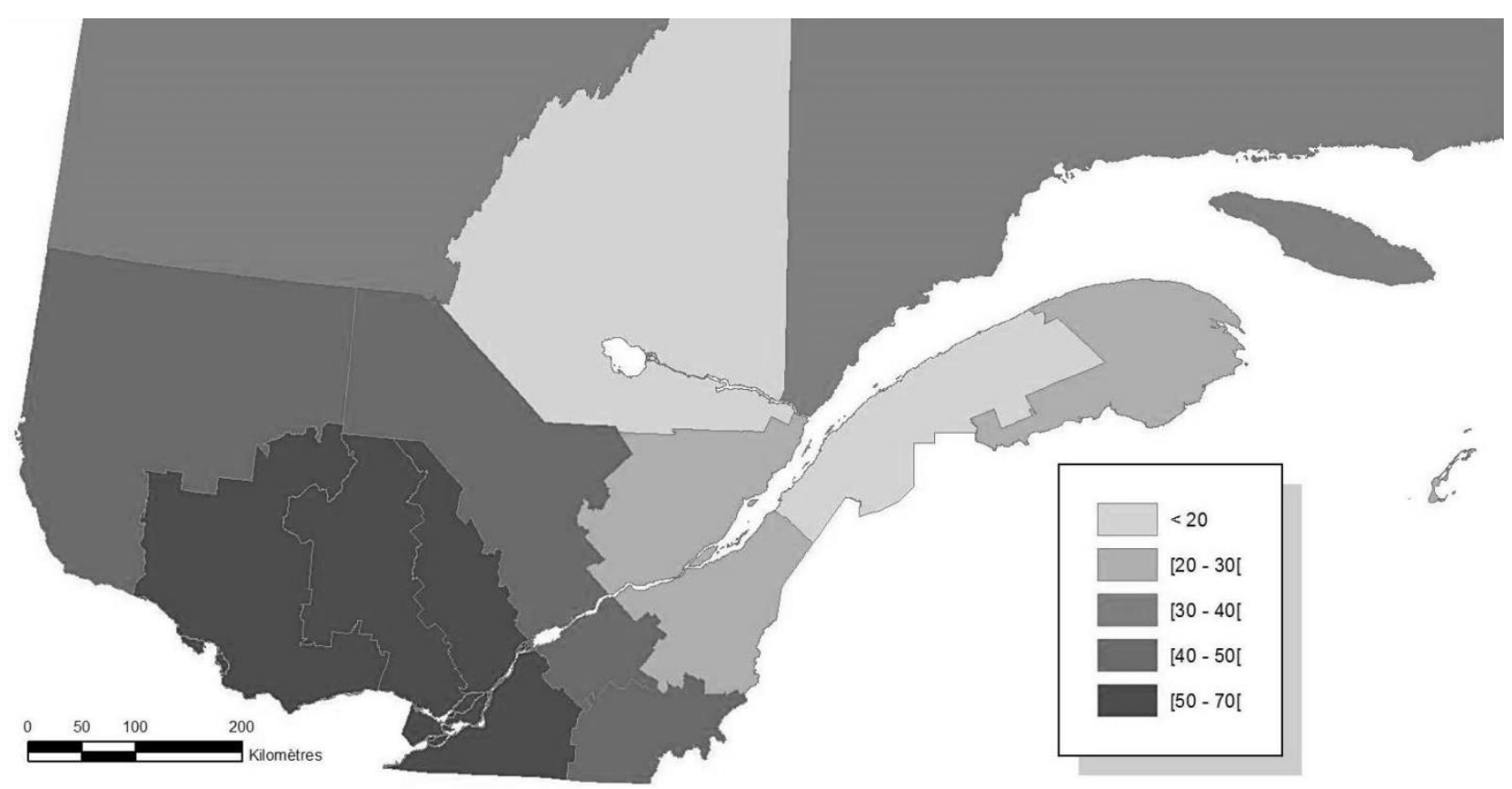


Figure 6: Proportion (\%) of genealogies in each Quebec region containing at least one Scottish founder

Note : Map produced at the Centre interuniversitaire d'études québécoises.

Source of data : BALSAC population database.

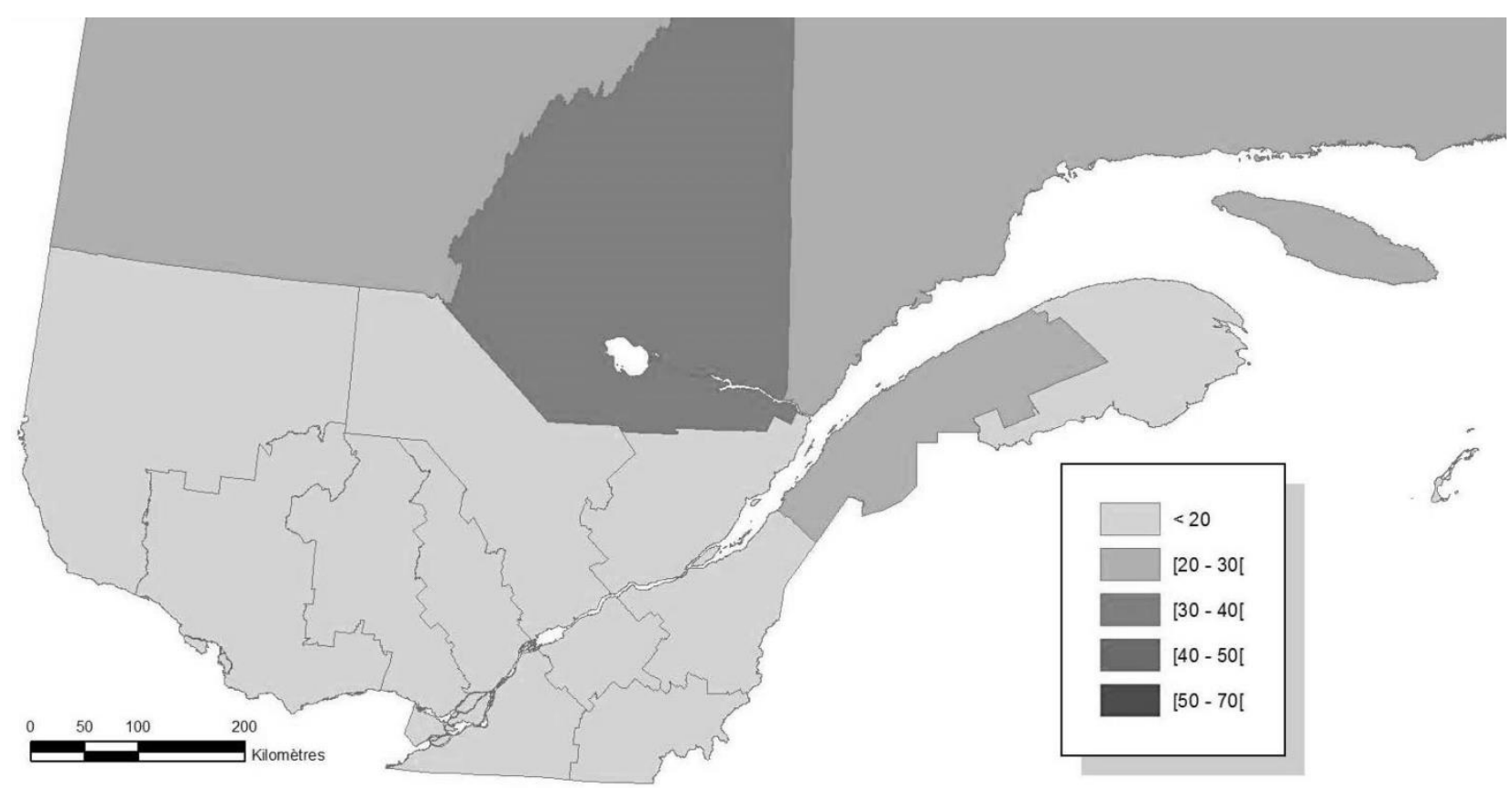


Figure 7: Genetic contribution (\%o) of English founders in each Quebec region

Note : Map produced at the Centre interuniversitaire d'études québécoises.

Source of data : BALSAC population database.

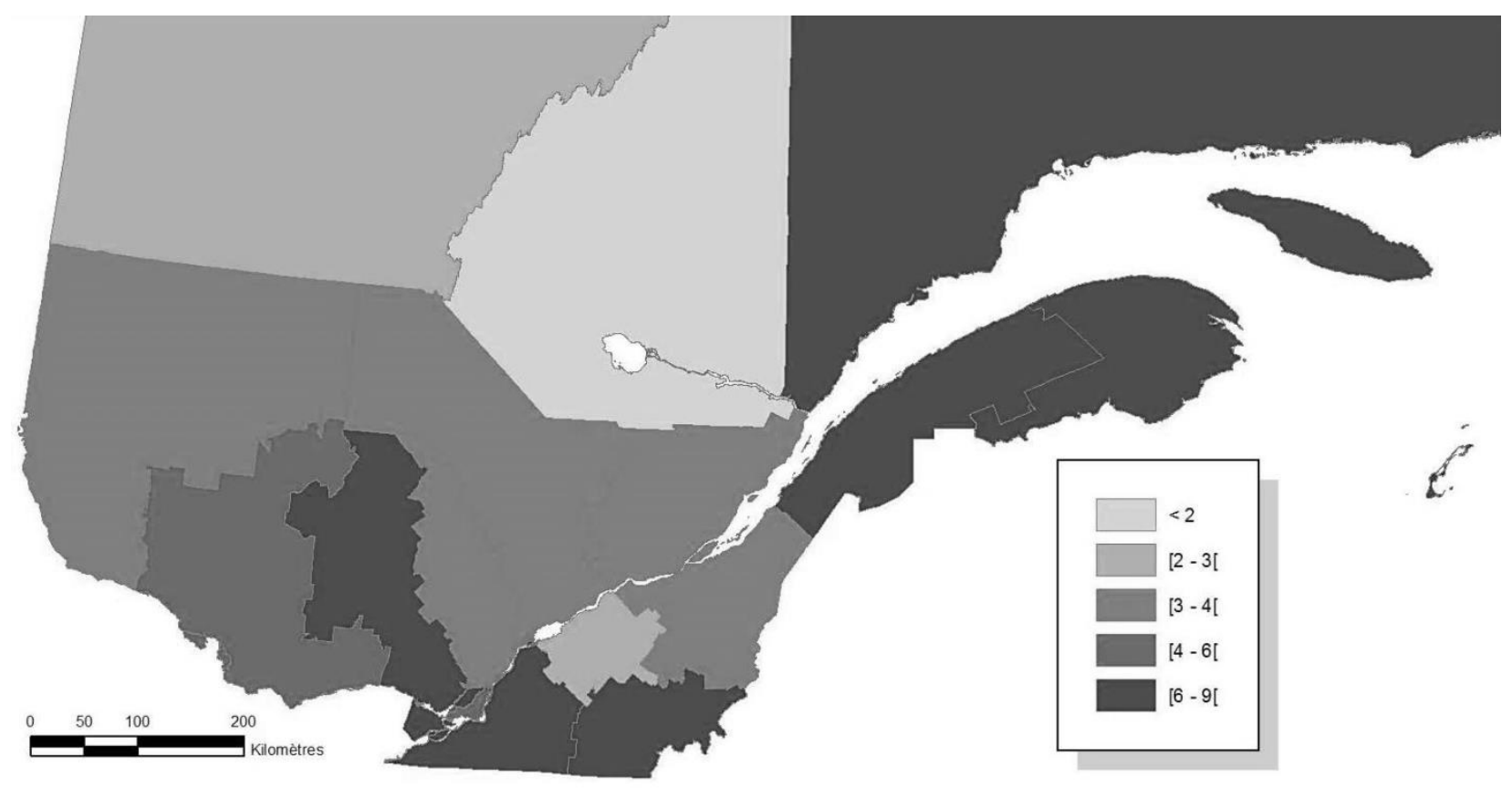


Figure 8: Genetic contribution (\%) of Scottish founders in each Quebec region

Note : Map produced at the Centre interuniversitaire d'études québécoises.

Source of data : BALSAC population database.

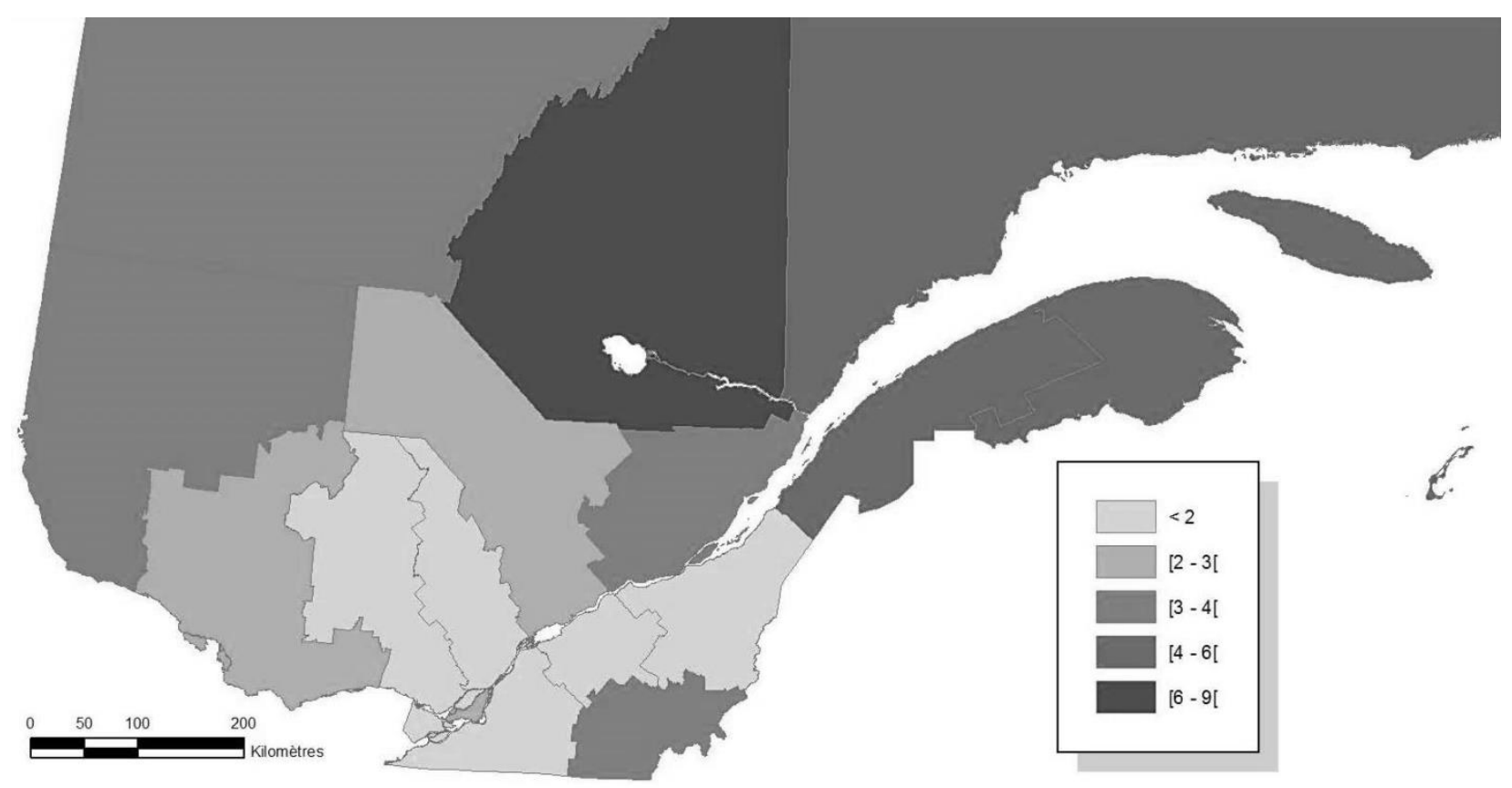


Table 1: Year of first record, and contemporary population of the 17 Quebec regions

\begin{tabular}{|c|c|c|c|c|}
\hline \multicolumn{2}{|r|}{ Region $^{a}$} & \multirow{2}{*}{$\begin{array}{c}\text { Year of first } \\
\text { record }^{b}\end{array}$} & \multicolumn{2}{|c|}{ Population in $2014^{\mathrm{C}}$} \\
\hline no & name & & $\mathbf{N}$ & $\%$ \\
\hline 01 & Bas-Saint-Laurent & 1685 & 200,292 & 2.4 \\
\hline 02 & Saguenay-Lac-Saint-Jean & 1842 & 277,786 & 3.4 \\
\hline 03 & Capitale-Nationale & 1621 & 731,838 & 8.9 \\
\hline 04 & Mauricie & 1645 & 266,794 & 3.2 \\
\hline 05 & Estrie & 1824 & 320,008 & 3.9 \\
\hline 06 & Montréal & 1647 & $1,988,243$ & 24.2 \\
\hline 07 & Outaouais & 1817 & 383,182 & 4.7 \\
\hline 08 & Abitibi-Témiscamingue & 1891 & 147,868 & 1,8 \\
\hline 09 & Côte-Nord & 1830 & 94,906 & 1.2 \\
\hline 10 & Nord-du-Québec & 1936 & 44,256 & 0.5 \\
\hline 11 & Gaspésie-îles-de-la-Madeleine & 1693 & 92,472 & 1.1 \\
\hline 12 & Chaudière-Appalaches & 1679 & 419,755 & 5.1 \\
\hline 13 & Laval & 1679 & 420,870 & 5.1 \\
\hline 14 & Lanaudière & 1672 & 492,234 & 6.0 \\
\hline 15 & Laurentides & 1690 & 586,051 & 7.1 \\
\hline 16 & Montérégie & 1668 & $1,508,127$ & 18.4 \\
\hline 17 & Centre-du-Québec & 1671 & 239,990 & 2.9 \\
\hline & Province of Québec & 1621 & $8,214,672$ & 100.0 \\
\hline
\end{tabular}

${ }^{a}$ Region numbers and names are those used by the Institut de la statistique du Québec (2015).

$\mathrm{b}$ Earliest marriage year among all marriages identified in the ascending genealogies of each region (source : BALSAC population database).

c Source : Institut de la statistique du Québec (2015). 
Table 2: Characteristics of the genealogies

\begin{tabular}{|c|c|c|c|c|c|c|}
\hline no & Region & $\begin{array}{c}\text { Total } \\
\text { number of } \\
\text { ancestors } \\
(1) \\
\end{array}$ & $\begin{array}{c}\text { Number of } \\
\text { distinct } \\
\text { ancestors } \\
(2) \\
\end{array}$ & $\begin{array}{c}\text { Mean number of } \\
\text { occurrences } \\
\text { per ancestor } \\
(1) /(2) \\
\end{array}$ & $\begin{array}{c}\text { Mean } \\
\text { genealogical } \\
\text { depth } \\
\text { (generations) }\end{array}$ & $\begin{array}{c}\text { Maximal } \\
\text { genealogical } \\
\text { depth } \\
\text { (generations) }\end{array}$ \\
\hline 01 & Bas-St-Laurent & $1,170,372$ & 41,502 & 28.2 & 10.1 & 16 \\
\hline 02 & $\begin{array}{l}\text { Saguenay-Lac- } \\
\text { St-Jean }\end{array}$ & $1,475,384$ & 43,855 & 33.6 & 10.6 & 16 \\
\hline 03 & $\begin{array}{l}\text { Capitale- } \\
\text { Nationale }\end{array}$ & $1,200,070$ & 61,163 & 19.6 & 10.2 & 16 \\
\hline 04 & Mauricie & $1,106,040$ & 57,448 & 19.3 & 10.1 & 16 \\
\hline 05 & Estrie & $1,244,488$ & 64,418 & 19.3 & 10.2 & 16 \\
\hline 06 & Montréal & $1,051,180$ & 73,691 & 14.3 & 9.8 & 16 \\
\hline 07 & Outaouais & $1,057,418$ & 57,773 & 18.3 & 9.6 & 16 \\
\hline 08 & $\begin{array}{l}\text { Abitibi- } \\
\text { Témiscamingue }\end{array}$ & $1,204,388$ & 68,617 & 17.6 & 10.2 & 17 \\
\hline 09 & Côte-Nord & $1,145,144$ & 48,219 & 23.7 & 9.7 & 17 \\
\hline 10 & Nord-du-Québec & $1,313,700$ & 64,886 & 20.2 & 10.3 & 16 \\
\hline 11 & $\begin{array}{l}\text { Gaspésie-Îles- } \\
\text { de-la-Madeleine }\end{array}$ & 871,242 & 36,077 & 24.1 & 9.2 & 18 \\
\hline 12 & $\begin{array}{l}\text { Chaudière- } \\
\text { Appalaches }\end{array}$ & $1,243,026$ & 48,645 & 25.6 & 10.4 & 16 \\
\hline 13 & Laval & $1,172,562$ & 75,215 & 15.6 & 10.1 & 16 \\
\hline 14 & Lanaudière & $1,104,812$ & 64,421 & 17.1 & 10.1 & 16 \\
\hline 15 & Laurentides & $1,167,590$ & 66,482 & 17.6 & 10.2 & 17 \\
\hline 16 & Montérégie & 992,616 & 69,794 & 14.2 & 9.7 & 16 \\
\hline 17 & $\begin{array}{l}\text { Centre-du- } \\
\text { Québec }\end{array}$ & $1,030,430$ & 54,442 & 18.9 & 10.1 & 16 \\
\hline
\end{tabular}

Source : BALSAC population database. 
Table 3: Number of English and Scottish founders identified in the genealogies

\begin{tabular}{|c|c|c|c|c|c|c|}
\hline no & Region & $\begin{array}{c}\text { Total } \\
\text { number } \\
\text { of founders }\end{array}$ & $\begin{array}{c}\text { Number of } \\
\text { English } \\
\text { founders }\end{array}$ & $\begin{array}{l}\text { Number of } \\
\text { Scottish } \\
\text { founders }\end{array}$ & $\begin{array}{c}\text { Proportion of } \\
\text { English } \\
\text { founders (\%) }\end{array}$ & $\begin{array}{c}\text { Proportion of } \\
\text { Scottish } \\
\text { founders (\%) }\end{array}$ \\
\hline \multirow{2}{*}{$\begin{array}{l}01 \\
02\end{array}$} & \multirow{2}{*}{$\begin{array}{l}\text { Bas-St-Laurent } \\
\text { Saguenay-Lac- } \\
\text { St-Jean }\end{array}$} & 3,863 & 25 & 26 & 0.65 & 0.67 \\
\hline & & 4,005 & 19 & 25 & 0.47 & 0.62 \\
\hline 03 & $\begin{array}{l}\text { Capitale- } \\
\text { Nationale }\end{array}$ & 5,006 & 33 & 39 & 0.66 & 0.78 \\
\hline 04 & Mauricie & 4,905 & 24 & 22 & 0.49 & 0.45 \\
\hline 05 & Estrie & 5,296 & 35 & 36 & 0.66 & 0.68 \\
\hline 06 & Montréal & 6,190 & 38 & 36 & 0.61 & 0.58 \\
\hline \multirow{2}{*}{$\begin{array}{l}07 \\
08\end{array}$} & \multirow{2}{*}{$\begin{array}{l}\text { Outaouais } \\
\text { Abitibi- } \\
\text { Témiscamingue }\end{array}$} & 5,348 & 33 & 18 & 0.62 & 0.34 \\
\hline & & 5,473 & 38 & 35 & 0.69 & 0.64 \\
\hline 09 & Côte-Nord & 4,933 & 33 & 32 & 0.67 & 0.65 \\
\hline \multirow{2}{*}{$\begin{array}{l}10 \\
11\end{array}$} & \multirow{2}{*}{$\begin{array}{l}\text { Nord-du-Québec } \\
\text { Gaspésie-îles-de- } \\
\text { la-Madeleine }\end{array}$} & 5,259 & 32 & 33 & 0.61 & 0.63 \\
\hline & & 4,171 & 35 & 26 & 0.84 & 0.62 \\
\hline 12 & $\begin{array}{l}\text { Chaudière- } \\
\text { Appalaches }\end{array}$ & 3,984 & 19 & 18 & 0.48 & 0.45 \\
\hline 13 & \multirow{2}{*}{$\begin{array}{l}\text { Laval } \\
\text { Lanaudière }\end{array}$} & 5,827 & 47 & 30 & 0.81 & 0.51 \\
\hline \multirow{2}{*}{$\begin{array}{l}14 \\
15\end{array}$} & & 5,390 & 26 & 14 & 0.48 & 0.26 \\
\hline & Laurentides & 5,408 & 41 & 16 & 0.76 & 0.30 \\
\hline \multirow{3}{*}{$\begin{array}{l}16 \\
17\end{array}$} & \multirow{2}{*}{$\begin{array}{l}\text { Montérégie } \\
\text { Centre-du- } \\
\text { Québec }\end{array}$} & 5,602 & 46 & 18 & 0.82 & 0.32 \\
\hline & & 4,722 & 25 & 18 & 0.53 & 0.38 \\
\hline & All regions & 10,483 & 194 & 122 & 1.85 & 1.16 \\
\hline
\end{tabular}

Source : BALSAC population database. 
Table 4: Sex and period of marriage (\%) of the English and Scottish founders identified in the genealogies

\begin{tabular}{clcc}
\hline & & $\begin{array}{c}\text { English founders } \\
(\mathrm{n}=194)\end{array}$ & $\begin{array}{c}\text { Scottish founders } \\
(\mathrm{n}=122)\end{array}$ \\
\hline \multirow{2}{*}{ Sex } & Male & 73 & 75 \\
& Female & 27 & 25 \\
& Total & 100 & 100 \\
\hline \multirow{5}{*}{ Period of } & Before 1760 & 10 & 4 \\
marriage & $1760-1779$ & 15 & 39 \\
& $1780-1799$ & 22 & 25 \\
& $1800-1819$ & 11 & 7 \\
& $1820-1839$ & 12 & 10 \\
& $1840-1859$ & 12 & 7 \\
& After 1859 & 18 & 8 \\
& Total & 100 & 100 \\
\hline
\end{tabular}

Source : BALSAC population database. 
Table 5: Places of origin of English and Scottish founders

\begin{tabular}{|c|c|c|c|}
\hline \multicolumn{2}{|c|}{ English founders } & \multicolumn{2}{|c|}{ Scottish founders } \\
\hline Buckinghamshire & 1 & Aberdeenshire & 12 \\
\hline Cheshire & 1 & Angus & 1 \\
\hline Cumberland & 2 & Argyll & 4 \\
\hline Devon & 4 & Ayrshire & 1 \\
\hline Dorset & 4 & Berwickshire & 1 \\
\hline Essex & 2 & Caithness & 1 \\
\hline Gloucestershire & 4 & Dumfries & 3 \\
\hline Hampshire & 2 & Edinburgh & 6 \\
\hline Herefordshire & 1 & Haddingtonshire & 2 \\
\hline Kent & 3 & Hebrides (Inner) & 3 \\
\hline Lancashire & 11 & Hebrides (Outer) & 8 \\
\hline London & 26 & Inverness-shire & 14 \\
\hline Middlesex & 1 & Lanarkshire & 3 \\
\hline Norfolk & 3 & Midlothian & 1 \\
\hline Nottinghamshire & 1 & Moray & 2 \\
\hline Staffordshire & 2 & Perthshire & 4 \\
\hline Suffolk & 1 & Ross and Cromarty & 3 \\
\hline Sussex & 3 & Roxburghshire & 4 \\
\hline Wiltshire & 1 & Stirling & 1 \\
\hline Worcestershire & 1 & West Lothian & 1 \\
\hline Yorkshire & 5 & Total Scotland & 75 \\
\hline Total England & 79 & & \\
\hline Ilse of Man & 1 & & \\
\hline Jersey & 6 & & \\
\hline Wales & 1 & & \\
\hline
\end{tabular}

Source : BALSAC population database. 
Table 6: Characteristics of the ten most important English and Scottish founders of the Quebec population

a) English founders

\begin{tabular}{|c|c|c|c|c|c|c|c|c|}
\hline Surname & First name & Origin & $\begin{array}{c}\text { Year of } \\
\text { marriage }\end{array}$ & Spouse name & $\begin{array}{c}\text { Numbe } \\
\text { sons }\end{array}$ & $\begin{array}{c}\text { of married cl } \\
\text { daughters }\end{array}$ & $\begin{array}{r}\text { hildren } \\
\text { Total }\end{array}$ & $\begin{array}{c}\text { Number } \\
\text { of regions }\end{array}$ \\
\hline BOIRE & Elizabeth & England & 1682 & Jean Charbonneau & 1 & 7 & 8 & 17 \\
\hline BEARD & Abel & London & 1699 & Marguerite Desjardins & 1 & 4 & 5 & 12 \\
\hline FRY & Richard & London & 1723 & Louise Pothier & 2 & 5 & 7 & 17 \\
\hline JAMES & William & Pimperne, Dorset & 1703 & Catherine Limousin & 3 & 3 & 6 & 16 \\
\hline RICASSE & Samuel & London & 1717 & Charlotte Choret & 0 & 1 & 1 & 17 \\
\hline TAYLOR & Richard & Gloucester & 1712 & Marie Bolduc & 1 & 2 & 3 & 12 \\
\hline THOMAS & John & London & 1695 & Anne Duquet & 1 & 2 & 3 & 16 \\
\hline
\end{tabular}

b) Scottish founders

\begin{tabular}{|c|c|c|c|c|c|c|c|c|}
\hline Surname & First name & Origin & $\begin{array}{l}\text { Year of } \\
\text { marriage }\end{array}$ & Spouse name & $\begin{array}{c}\text { Number } \\
\text { sons }\end{array}$ & $\begin{array}{l}\text { ff married c } \\
\text { daughters }\end{array}$ & $\begin{array}{l}\text { hildren } \\
\text { Total }\end{array}$ & $\begin{array}{l}\text { Number } \\
\text { of regions }^{\mathrm{a}}\end{array}$ \\
\hline BLACKBURN & Hugh & Tranent, East Lothian & 1780 & Geneviève Gagnon & 8 & 4 & 12 & 12 \\
\hline CAMERON & Thomas & Inverness & 1772 & Françoise Roy & 3 & 2 & 5 & 12 \\
\hline FRASER & John & Boleskine, Highland & 1775 & Marguerite Vallée & 2 & 6 & 8 & 10 \\
\hline HAMILTON & Charles & Scotland & 1795 & $\begin{array}{c}\text { Euphrosine Rolet and } \\
\text { Charlotte Rolet }\end{array}$ & 3 & 7 & 10 & 10 \\
\hline MC DONALD & Alexander & Watten, Caithness & 1764 & Marie Deslauriers & 2 & 3 & 5 & 11 \\
\hline MC NICOLL & Duncan & Inveraray, Argyll & 1759 & Catherine Nicolas & 2 & 4 & 6 & 17 \\
\hline NICOLAS & Catherine & Dunkeld, Perthshire & 1759 & Duncan McNicoll & 2 & 4 & 6 & 17 \\
\hline REID & John & Inverness & 1714 & Catherine Primeau & 2 & 2 & 4 & 12 \\
\hline ROBINSON & John & Stirling & 1775 & Marguerite St-Pierre & 5 & 5 & 10 & 11 \\
\hline ROSS & William & Girvan, Ayrshire & 1764 & Josephte Proulx & 5 & 0 & 5 & 16 \\
\hline
\end{tabular}

${ }^{\mathrm{a}}$ Corresponds to the number of regions where the founders appear at least once in the genealogies. Source : BALSAC population database. 